\title{
Corelation Between Sum of Precordial ST Depression in Acute Inferior Myocardial Infarction with Stenosis Severity of Left Anterior Descending Artery
}

\author{
Kartika br. Karo ${ }^{1 *}$, Andre Pasha Ketaren ${ }^{2}$, Refli Hasan $^{3}$, Harris Hasan $^{4}$, \\ Zulfikri Mukhtar ${ }^{4}$, Anggia C Lubis ${ }^{6}$ \\ 1,2,3,4,5,6 Department of Cardiology and Vascular Medicine, Universitas Sumatera Utara, Adam Malik \\ Hospital, Medan, North Sumatera, Indonesia
}

\begin{abstract}
There were many studies proved that precordial ST depression in Inferior STEMI show LAD disease from angiografi, but there were also many who unproved. Altought LAD disease was not the main cause of precordial ST depression in Inferior STEMI, but there were many patients with Inferior STEMI who had high grade LAD disease. Sum of precordial ST depression is one of ECG criteria that can help us to prove it. The aim of this study in to know if there is corelation between sum of precordial ST depression with LAD disease and the severity of LAD disease in Inferior STEMI patients with precordial ST depression. We analized 60 patients inferior STEMI with precordial ST depression onset less than 24 hours that hospitalized in Haji Adam Malik General Hospital since December 2013June 2017. Patients were divided in to 4 groups based on sum of precordial ST depression. Bivariate analysis were made to see the corelation between sum of precordial ST depression with LAD disease and severity of LAD, $p$ value $<0.05$ is statistically significant. Bivariate analysis show that there is strong corelation between sum of precordial ST depression with LAD disease $(p=0.01)$. Sum of precordial ST depression also corelate with severity of LAD $(p=0.01)$. There are also corelation with location of the lesion in proximal LAD and the complexity of the lesion but not statistically significant $(\mathrm{p}=0.233$ and $\mathrm{p}=0.102)$. Analysis ROC curve sum of precordial ST depression to LAD disease give the cut off $\geq 5.15 \mathrm{~mm}$ with sensitivity $70 \%$ and spesificity $76.2 \%$ (AUC $0,752,95 \%$ CI: $0,620-0,883 p<0,001)$. There is strong corelation between sum of precordial ST depression with high grade LAD disease. The more the sum of precordial ST depression the more posibility high degree LAD disease $(\mathrm{p}=0.01)$.
\end{abstract}

Keyword: Sum of Precordial ST Depression, Inferior STEMI, LAD Disease

Received 28 December 2018 | Revised 15 January 2019 | Accepted 31 January 2019

${ }^{*}$ Corresponding author at: Faculty of Medicine, Universitas Sumatera Utara, Medan, Indonesia 


\section{Introduction}

About $60 \%$ patients with inferior STEMI also have ST depression in precordial lead. Initially, precordial ST depression is only considered as ECG phenomenon due to reciprocal reflection of electrical currents in the inferior infarct region without any anatomical or physiological significance. However, this seems to apply only to a minority of inferior STEMI patients. Most studies have shown that patients with precordial ST depression have a larger area of infarction, characterized by higher cardiac enzyme levels, heavier regional LV wall movement abnormalities, and lower Ejection Fraction (EF) [1]-[5]. There is an opinion that inferior STEMI with precordial ST depression is multivessel coronary disease theory which states that precordial ST depression can be caused by ischemic left anterior wall of the left ventricle caused by LAD disease. This is first described by Blumgart (1940) which states the term "Ischemia at distance" meaning the total occlusion of a coronary artery can cause ischemia in the myocardium supplied by another coronary artery, if this other coronary artery has a critical narrowing and depends on collateral blood flow from the first coronary artery.6 Many studies support the involvement of LAD disease by using angiography criteria [4], [6]-[8] while other studies do not support. Although these data do not show LAD disease as major cause of precordial ST depression, they indicate that some inferior IMAEST patients do have high grade LAD disease [9]-[11]. So, in some patients, ishemia at distance is true. Some ECG images can help in detecting this. A deeper ST depression degree may increase the tendency for LAD disease, as reported by Haraphongse (1983), that all patients (100\%) who had a precordial ST depression of more than $0.3 \mathrm{mV}$ had LAD disease, compared to only $60 \%$ patients with preecordial DSST $0.2-0.3 \mathrm{mV}$ and about $33 \%$ in patients with precordial DSST less than $0.2 \mathrm{mV}$.

Because there is still a difference of opinion about precordial ST depression as a marker of LAD involvement and also a specific study of ST depression correlation with the degree of severity of LAD stenosis has also never been conducted researcher aims to determine whether there is a correlation between depression ST depression on lead precordial with LAD involvement and the severity of LAD stenosis. In addition, the researchers also want to counteract the sensitivity and specificity of each preordial lead associated with LAD involvement.

\section{Methodology}

This study is a retrospective single centre study of inferior STEMI patients during the period December 2013 through June 2017. Inferior STEMI patients $<24$ hours onset with precordial ST depression, no history of acute MI, no history of heart failure, and no history use of digitalis were included in this study. Patients with ECG bundle branch block (BBB), Left Ventricle Hyperthrophy (LVH), rhythm of the pacemaker, experienced hypokalemia at admission and patients with ECG images not eligible for reading were excluded from the study. Inferior STEMI is define by the presence of typical chest pain infarction (chest pain with duration $>20 \mathrm{~min}$, may 
be accompanied by spread to the neck, lower jaw or left arm, not fully responding with nitrates, may be accompanied by symptoms of activation of the autonomic nervous system such as nausea, vomiting and sweat ), an increase and / or decrease in the value of the cardiac enzyme (troponin) at least one value above the 99th percentile of normal values accompanied by ST segment elevation in II, III, aVF leads assessed J point, in two related leads, $\geq 0.25 \mathrm{mV}$ in men $<40$ years, $\geq 0.2 \mathrm{mV}$ in men $>40$ years, or $\geq 0.15 \mathrm{mV}$ in women at lead V2-V3, and / or $\geq 0.1 \mathrm{mV}$ in other leads. Precordial ST segment depression (DSST) is defined as horizontal ST segment depression or downsloping $\geq 1 \mathrm{~mm}$ in at least two of the six precordial leads $\mathrm{V} 1$ to $\mathrm{V} 6$ in patients with inferior IMAEST [12], [13]. The researcher will examine the patient's medical record for anamnesis, physical examination, early ECG, thoracic photo, cardiac enzyme examination (CKMB and Troponin T/I), echocardiography, and coronary angiography that have been done during hospitalization. All these data will be carefully recorded. Of all patients include in this study, the initial critical data evaluated were 12 lead ECG at presentation using a speed of $25 \mathrm{~mm} / \mathrm{s}$ and a scale of $10 \mathrm{mV} / \mathrm{mm}$.

The depth measurements of ST depression on the ECG will be performed manually using a 150 mm Krisbow (KW0600352) caliper dial micrometer and magnifying glass. The depth of ST depression will be measured by the distance between two lines. Line (1) is an isoelectric line connecting P and Q (PR interval) waves. Line (2) is part of ST segment depression taken 40-80 $\mathrm{ms}$ from J Point. The distance between the two lines will be measured with a caliper dial micrometer and summed from each precursor lead (V1-V6) of DSST ( $\Sigma$ DSST). Measurement will be performed by two cardiologists who do not know the angiography of the study subjects. Then will be analyzed intra-observer variability. Assessment of the involvement and severity of LAD stenosis from angiography results will be made by two intervention cardiologists who are also unaware of the study's subject's ECG. Based on these measurements, the patient will be grouped into several quartiles and see which depth is best in predicting LAD involvement. Afterwards, it was assessed that the sum of ST depression depth relationship with LAD stenosis severity. It also analyzes the sensitivity and specificity of each associated precordial lead to predict LAD involvement.

All statistical analyses were performed using statistical software, and a $p$ value $<0.05$ was considered significant. Receiver operating characteristic curve analysis was used to determine the optimum cut-off values of sum ST depression to predict the involvement of LAD and severity of LAD stenosis. Clinical, laboratory, and procedural data were compared with the use of Student $t$ or ManneWhitney $U$ test for continuous variables (expressed as mean standard deviation for parametric variables and median and interquartile ranges [25 to 75 percentile levels] for nonparametric variables) and the chi-square or Fisher's exact test for categorical variables (expressed as counts and percentages). Continuous variables were analyzed for normal distribution using the Kolmogorov Smirnov test. 


\section{Results}

The number of inferior IMAEST patients from December 2013 to June 2017 was 184 persons, of which 60 samples of inferior IMAEST onset $<24$ hours with precursor DSST features that met the inclusion and exclusion criteria to be included in the study. From the description of demographic data of research subjects (Table 1) it can be seen that there were no significant differences in age, sex and weight in each quartile. For CHD risk factor's there was also no significant difference for all risk factors (hypertension, DM, dyslipidemia and smoking) between each quartile. For the initial presentation data of the study subjects there was no significant difference in mean systolic and diastolic blood pressure, heart rate, cardiac enzyme, and TIMI score among each quartile. A significant difference was found in the mean onset of chest pain and the mean left ventricular ejection fraction. The subjects in quartile IV (sum ST depression $>7.88$ $\mathrm{mm}$ ) were seen to have an earlier onset of chest pain and a lower ejection fraction than the other quartiles $(\mathrm{p}=0.038 ; \mathrm{p}=0.029)$.

Table 2 shows the relationship of sum of ST depression to LAD stenosis. In the quartile I (sum of ST depression $<3.24 \mathrm{~mm}$ ) there were $33.3 \%$ subjects with stenosis in LAD. In the quartile II (3.24-5.35) seen an increase in the number of subjects with LAD stenosis is $60 \%$. In quartile III group $(5.35-7.88 \mathrm{~mm})$ this number is increasing where there are $80 \%$ of subjects with LAD stenosis. Subjects with LAD stenosis were most prevalent in the quartile IV $(>7.88 \mathrm{~mm})$ of $86.7 \%$.

Based on the histogram graph in Figure 1 it is found that the more in sum of ST depression the higher the number of subjects who have stenosis in LAD. The analysis result using chi square test showed that there was a significant correlation between depth of sum ST depression amount to LAD stenosis $(\mathrm{p}=0,01)$.

Based on sum of ST depression it is seen that the more in ST depression the more the LAD severity level increases. In the Quartile I (depth $<3.24 \mathrm{~mm}$ ), the mean percentage of LAD severity was only $21.67 \%(\mathrm{SD}=32.16 \%)$. Furthermore, in group Quartile II (depth $3.24-5.34 \mathrm{~mm}$ ), mean of LAD severity increased to $48 \%$ ( $\mathrm{SD}=43,62 \%$ ). In the Quartile III (depth $5.35-7.88 \mathrm{~mm}$ ), the average LAD severity continued to increase to $63.6 \%(\mathrm{SD}=37.18 \%)$. In the Quartile IV(depth> $7.88 \mathrm{~mm})$, the mean LAD severity was $68.6 \%(\mathrm{SD}=33.71 \%)$. Figure 2 shows that as large as the depth of ST depression, stenosis in LAD is more severe.

Table 1 Baseline Characteristic 


\begin{tabular}{|c|c|c|c|c|c|}
\hline \multirow[b]{2}{*}{ Caracteristics } & \multicolumn{3}{|c|}{$\begin{array}{l}\text { Sum of Precordial ST } \\
\text { Depression }\end{array}$} & \multicolumn{2}{|c|}{$\mathbf{p}$} \\
\hline & $\begin{array}{l}<3,24 \\
(n=15)\end{array}$ & $\begin{array}{c}3,24- \\
5,34 \\
(n=15)\end{array}$ & $\begin{array}{l}5,35- \\
7,88 \\
(n=15)\end{array}$ & $\begin{array}{l}>7,88 \\
(n=15)\end{array}$ & \\
\hline $\begin{array}{l}\text { Age, mean } \\
\text { (SD), years } \\
\text { Sex Category, } \\
\text { n (\%) }\end{array}$ & $\begin{array}{l}53,53 \\
(8,95)\end{array}$ & $\begin{array}{l}56,07 \\
(6,12)\end{array}$ & $\begin{array}{l}55,87 \\
(7,75)\end{array}$ & $\begin{array}{l}52,27 \\
(6,65)\end{array}$ & $0,436^{2}$ \\
\hline Male & $12(80)$ & $\begin{array}{c}14 \\
(93,3)\end{array}$ & $\begin{array}{c}10 \\
(66,7)\end{array}$ & $\begin{array}{c}13 \\
(86,7)\end{array}$ & $0,273^{8}$ \\
\hline Femsle & $3(20)$ & $1(6,7)$ & $5(33,3)$ & $2(13,3)$ & \\
\hline $\begin{array}{l}\text { Body Weight, } \\
\text { mean (SD), kg } \\
\text { Risk Factor, n } \\
\text { (\%) }\end{array}$ & $\begin{array}{l}67,87 \\
(7,88)\end{array}$ & $\begin{array}{c}64,4 \\
(6,53)\end{array}$ & $\begin{array}{c}67 \\
(8,31)\end{array}$ & $\begin{array}{l}68,93 \\
(7,65)\end{array}$ & $0,415^{2}$ \\
\hline Hipertension & $5(33,3)$ & $4(26,7)$ & $9(60)$ & $\begin{array}{c}10 \\
(66,7)\end{array}$ & $0,073^{2}$ \\
\hline DM & $4(26,7)$ & $6(40)$ & $8(53,3)$ & $6(40)$ & $0,528^{2}$ \\
\hline Dislipidemia & $7(46,7)$ & $12(80)$ & $\begin{array}{c}10 \\
(66,7)\end{array}$ & $9(60)$ & $0,292^{\circ}$ \\
\hline Smoker & $12(80)$ & $\begin{array}{c}14 \\
(93,3)\end{array}$ & $9(60)$ & $\begin{array}{c}13 \\
(86,7)\end{array}$ & $0,120^{\circ}$ \\
\hline $\begin{array}{l}\text { SBP, mean } \\
\text { (SD), mmHg }\end{array}$ & $\begin{array}{c}105 \\
(27,32)\end{array}$ & $\begin{array}{l}112,67 \\
(19,45)\end{array}$ & $\begin{array}{l}115,33 \\
(23,87)\end{array}$ & $\begin{array}{c}124 \\
(41,37)\end{array}$ & $0,598^{\circ}$ \\
\hline $\begin{array}{l}\mathrm{DBP} \text {, mean } \\
\text { (SD), } \mathrm{mmHg}\end{array}$ & $\begin{array}{c}68,87 \\
(14,57)\end{array}$ & $\begin{array}{c}74 \\
(10,56)\end{array}$ & $\begin{array}{c}72,67 \\
(14,38)\end{array}$ & $\begin{array}{c}78 \\
(20,77)\end{array}$ & $0,567^{\circ}$ \\
\hline $\begin{array}{l}\text { Heart Rate, } \\
\text { mean (SD), } \\
\mathrm{x} / \mathrm{m}\end{array}$ & $\begin{array}{c}63,53 \\
(17,68)\end{array}$ & $\begin{array}{c}66,93 \\
(12,13)\end{array}$ & $\begin{array}{c}74,73 \\
(21,17)\end{array}$ & $\begin{array}{c}71,27 \\
(17,85)\end{array}$ & $0,327^{2}$ \\
\hline $\begin{array}{l}\text { Onsat, mean } \\
\text { (SD), hour }\end{array}$ & $\begin{array}{c}16,9 \\
(17,54)\end{array}$ & $\begin{array}{c}16,27 \\
(19,71)\end{array}$ & $\begin{array}{c}25 \\
(18,5)\end{array}$ & $\begin{array}{c}11,27 \\
(13,87)\end{array}$ & $0,038^{\circ}$ \\
\hline$<12 \mathrm{~h}$ & $8(53,3)$ & $9(60)$ & $7(46,7)$ & $\begin{array}{c}11 \\
(73,3)\end{array}$ & $0,494^{2}$ \\
\hline$>12 \mathrm{~h}$ & $7(46,7)$ & $6(40)$ & $8(53,3)$ & $4(26,7)$ & \\
\hline $\begin{array}{l}\text { CKMB, mean } \\
\text { (SD) }\end{array}$ & $\begin{array}{l}176,07 \\
(144,02)\end{array}$ & $\begin{array}{c}221,6 \\
(229,86)\end{array}$ & $\begin{array}{c}190 \\
(236,79)\end{array}$ & $\begin{array}{c}193 \\
(147,62)\end{array}$ & $0,955^{\circ}$ \\
\hline $\begin{array}{l}\mathrm{EF} \text {, mean } \\
\text { (SD) }\end{array}$ & $\begin{array}{c}54,47 \\
(7,8)\end{array}$ & $\begin{array}{l}47,53 \\
(9,78)\end{array}$ & $\begin{array}{c}48 \\
(5,46)\end{array}$ & $\begin{array}{l}45,2 \\
(9,67)\end{array}$ & $0,029^{\circ}$ \\
\hline TIM Risk & 3,6 & 3,73 & 3,93 & 3,8 & $0,928^{\circ}$ \\
\hline $\begin{array}{l}\text { score, mean } \\
\text { (SD) }\end{array}$ & $(1,84)$ & $(1,98)$ & $(1,44)$ & $(2,34)$ & \\
\hline CTR, n (\%) & & & & & \\
\hline $\begin{array}{l}<50 \% \\
>50 \%\end{array}$ & $\begin{array}{l}9(60) \\
6(40)\end{array}$ & $\begin{array}{l}8(53,3) \\
7(46,7)\end{array}$ & $\begin{array}{l}9(60) \\
6(40)\end{array}$ & $\begin{array}{l}6(40) \\
9(60)\end{array}$ & $0,658^{\circ}$ \\
\hline
\end{tabular}

Table 2 Relationship depth sum of ST depression with LAD stenosis

\begin{tabular}{cccc}
\hline $\begin{array}{c}\text { Depth Sum of ST } \\
\text { Depression, n (\%) }\end{array}$ & \multicolumn{2}{c}{ LAD Stenosis } & \multirow{2}{*}{ p* } \\
\cline { 2 - 3 } Quartile I $(<3.24 \mathrm{~mm})$ & $5(33,3)$ & $10(66,7)$ & 0,01 \\
$\begin{array}{c}\text { Quartile II(3.24 - 5.34 } \\
\mathrm{mm})\end{array}$ & $9(60)$ & $6(40)$ & \\
$\begin{array}{c}\text { Quartile III }(5.35-7.88 \\
\mathrm{mm})\end{array}$ & $12(80)$ & $3(20)$ & \\
QuartileIV(>7.88 mm) & $13(86,7)$ & $2(13,3)$ & \\
\hline
\end{tabular}

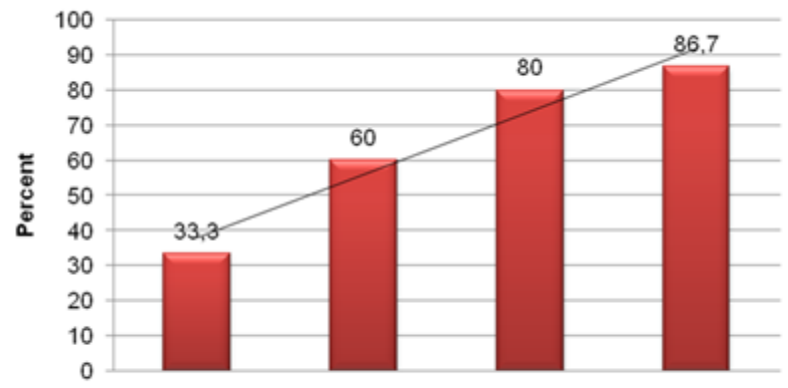


Figure 1 Relationship of sum of ST depression to LAD stenosis

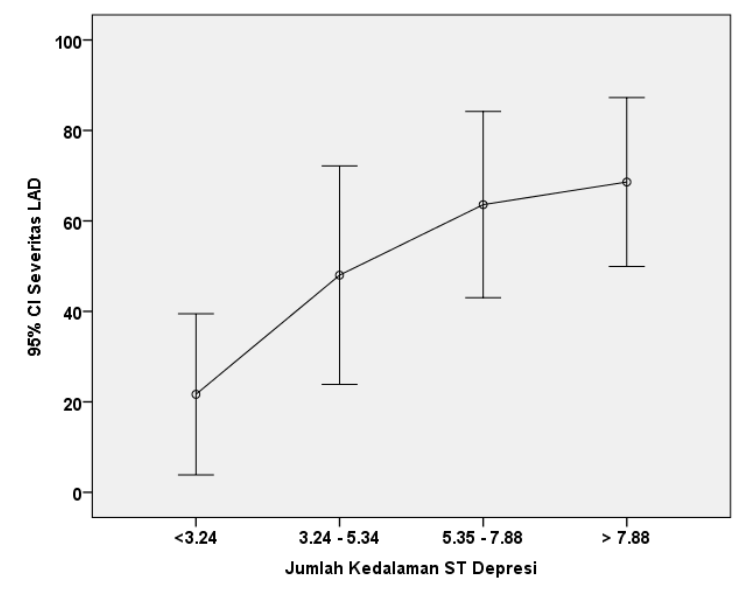

Figure 2 Relationship of depth sum ST depression to severity of stenosis in LAD

The highest sensitivity was achieved by all leads in predicting LAD by $56.4 \%$, and the lowest in V1V2 and V5V6 leads was only 5.1\%. The 100\% specificity can be achieved by a lead V5V6, followed by a lead of V1V2 with a specificity of $90.5 \%$ and a specific specificity by all leads of only $81 \%$. Based on the accuracy, the highest accuracy is obtained at $65 \%$ ie on all leads (V1V6).

Table 3 Sensivvity and Spesificity of precordial leads

\begin{tabular}{llccccccc}
\hline & & LAD & $\begin{array}{c}\text { Sensit } \\
\text { ivity }\end{array}$ & $\begin{array}{c}\text { Spesi } \\
\text { fisity }\end{array}$ & PPV, & NPV, & $\begin{array}{c}\text { Acur } \\
\text { acy }\end{array}$ \\
\cline { 3 - 8 } & & + & - & $\%$ & $\%$ & $\%$ & $\%$ & $\%$ \\
\hline V1V2 & Yes & 2 & 2 & 5,1 & 90,5 & 50 & 33,9 & 35 \\
& No & 37 & 19 & & & & & \\
\hline V1-V4 & Yes & 9 & 9 & 23,1 & 61,9 & 52,9 & 30,2 & 36,7 \\
& No & 30 & 13 & & & & & \\
\hline V3-V6 & Yes & 6 & 7 & 46,2 & 66,7 & 46,2 & 29,8 & 33,3 \\
& No & 33 & 14 & & & & & \\
\hline V5V6 & Yes & 2 & 0 & 5,1 & 100 & 100 & 36,2 & 38,3 \\
& No & 37 & 21 & & & & & \\
\hline V1-V6 & Yes & 22 & 4 & 56,4 & 81 & 84,6 & 50 & 65 \\
& No & 17 & 17 & & & & & \\
\hline
\end{tabular}

With the analysis using ROC curve, it can be seen that depth ST depth in this study has the ability to predict LAD because it has a value of Area Under Curve (AUC) of 75.2\% (95\% CI: $0.620-0.883$ ) with $\mathrm{p}=0.001, \mathrm{p}<0.05$. 
Based on the sensitivity and specificity curve of Figure 4, the Cut Off value for depth ST depth is $5.15 \mathrm{~mm}$. Using a cut off point of $5.15 \mathrm{~mm}$, the sensitivity of depth ST depth was $69.2 \%$ and specificity was $76.2 \%$. Positive Prediction Value (PPV) sum of ST depression $84.4 \%$ and Negative Prediction (NPV) value is $57.1 \%$, with an accuracy of $71.7 \%$.

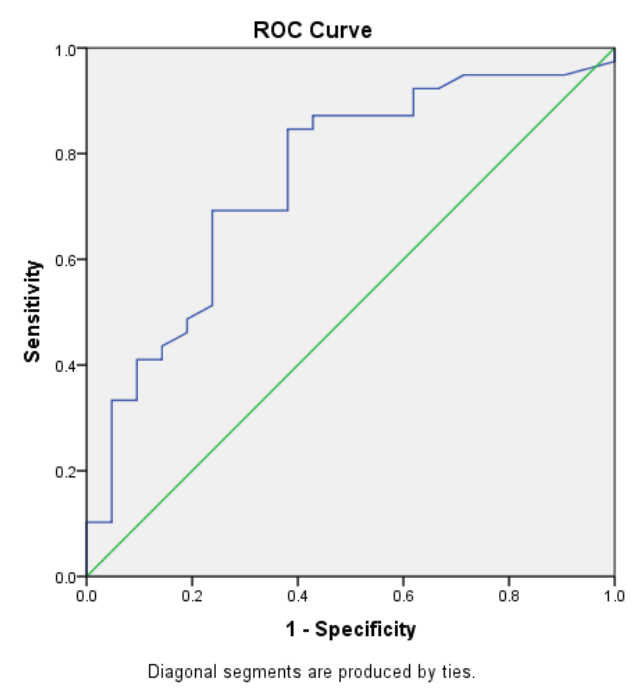

Figure 3 ROC curve sum of ST depression

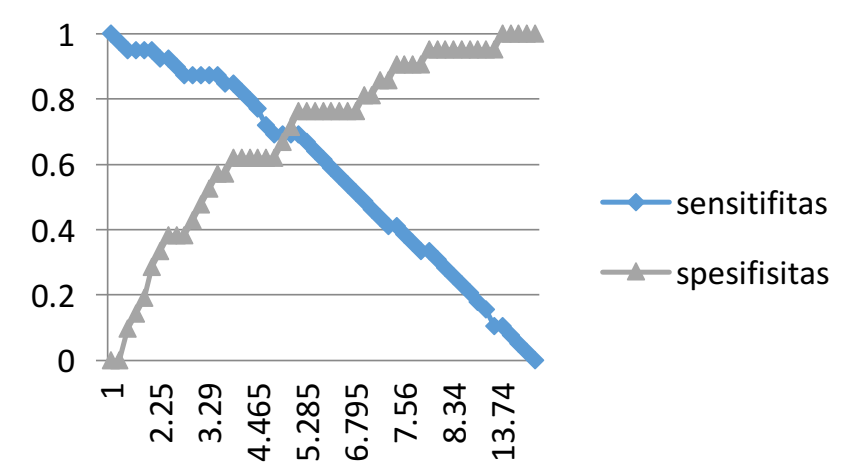

\section{Discussion}

In this study, there was a statistically significant relationship in terms sum of ST depression with Ejection Fraction $<40 \%$. Subjects with a precursor depth of ST depression $>7.88 \mathrm{~mm}$ had a lower mean ejection fraction than other quartiles having a lower depth of ST depression of precordial $(p=0.029)$. This is consistent with the results of previous studies by Lembo (1986) and Hlatky (1985) who argue that inferior IMAEST with precordial DSST $\geq 0.1 \mathrm{mV}$ is associated with a wider area of infarct, poor left ventricular function. For the onset of chest pain subjects with sum of ST depression $>7.88$ were seen to have lower onset rates $(p=0.038)$.

The results of this study support previous studies, in which Inferior STEMI patients with precordial ST depression did have high grade LAD disease. The deeper degrees of ST depression may increase the tendency for LAD disease, as reported by Haraphongse (1983), that all patients 
(100\%) who had sum of precordial ST depressions more than $0.3 \mathrm{mV}$ had LAD disease, compared to only $60 \%$ in patients with sum ST depression $0.2-0.3 \mathrm{mV}$ and about $33 \%$ in patients with less than $0.2 \mathrm{mV}$. In this study found the greater the number of sum ST depression then the possibility for stenosis in LAD is also higher $(\mathrm{p}=0.01))$. For the severity of LAD stenosis, subjects with sum of ST depression count $>7.88$ had a higher mean stenosis $(p=0.01)$. Seen on the graph of LAD severity that the greater the depth of sum ST depression the higher the degree of stenosis. This study suggests that in addition to indicating the presence of LAD involvement (as found in previous studies), the greater depth of sum ST depression is also a greater degree of stenosis severity weight. From the ROC curve analysis for the sum of ST depression depth there was a cut-off value of $\geq 5.15 \mathrm{~mm}$ giving $70 \%$ sensitivity and $76.2 \%$ specificity $\%$ (AUC $0,752,95 \%$ CI: $0,620-0,883 \mathrm{p}<0,001$ ). Positive Prediction Value (PPV) sum of ST depression amounts $84.4 \%$ and Negative Prediction (NPV) value is $57.1 \%$, with an accuracy of $71.7 \%$. to predict LAD involvement. Prior research by Harapongse (1983), which received a value of $>0.3 \mathrm{mV}(3 \mathrm{~mm})$ as a cut-off of LAD involvement. For the specific purpose of this study, the ST depression location in V1-V6 gave the best results when compared to other related precordial lead groups although the sensitivity and specificity numbers are not too high.

\section{References}

[1] H. Sato et al., "Right coronary artery occlusion: its role in the mechanism of precordial ST segment depression," Journal of the American College of Cardiology, vol. 14, no. 2, pp. 297-302, 1989.

[2] J. F. Brymer, F. Khaja, M. Marzilli, S. Goldstein, and J. Alban, “'Ischemia at a distance' during intermittent coronary artery occlusion: a coronary anatomic explanation," Journal of the American College of Cardiology, vol. 6, no. 1, pp. 41-45, 1985.

[3] Y. Birnbaum et al., "Prognostic significance of precordial ST segment depression on admission electrocardiogram in patients with inferior wall myocardial infarction," Journal of the American College of Cardiology, vol. 28, no. 2, pp. 313-318, 1996.

[4] K. Jennings, D. S. Reid, and D. G. Julian, ““ Reciprocal' depression of the ST segment in acute myocardial infarction.," Br Med J (Clin Res Ed), vol. 287, no. 6393, pp. 634-637, 1983.

[5] M. A. Hlatky, R. M. Califf, K. L. Lee, D. B. Pryor, G. S. Wagner, and R. A. Rosati, "Prognostic significance of precordial ST-segment depression during inferior acute myocardial infarction," American Journal of Cardiology, vol. 55, no. 4, pp. 325-329, 1985.

[6] C. H. Croft et al., "Clinical implications of anterior ST segment depression in patients with acute inferior myocardial infarction," American Journal of Cardiology, vol. 50, no. 3, pp. 428-436, 1982.

[7] W. C. Little, E. W. Rogers, and M. T. Sodums, "Mechanism of anterior ST segment depression during acute inferior myocardial infarction: observations during coronary thrombolysis," Annals of internal medicine, vol. 100, no. 2, pp. 226-229, 1984.

[8] J. R. Salcedo, M. G. Baird, R. J. Chambers, and D. S. Beanlands, "Significance of reciprocal ST segment depression in anterior precordial leads in acute inferior myocardial infarction: concomitant left anterior descending coronary artery disease?," The American journal of cardiology, vol. 48, no. 6, pp. 1003-1008, 1981.

[9] D. W. Ferguson, N. Pandian, J. M. Kioschos, M. L. Marcus, and C. W. White, "Angiographic evidence that reciprocal ST-segment depression during acute myocardial infarction does not indicate remote ischemia: analysis of 23 patients," American Journal of Cardiology, vol. 53, no. 1, pp. 55-62, 1984. 
[10]R. S. Gibson, H. L. Bishop, R. B. Stamm, R. S. Crampton, G. A. Beller, and R. P. Martin, "Value of early two dimensional echocardiography in patients with acute myocardial infarction," American Journal of Cardiology, vol. 49, no. 5, pp. 1110-1119, 1982.

[11]A. S. Lew et al., "Factors that determine the direction and magnitude of precordial STsegment deviations during inferior wall acute myocardial infarction," American Journal of Cardiology, vol. 55, no. 8, pp. 883-888, 1985.

[12]M. Haraphongse, B. I. Jugdutt, and R. E. Rossall, "Significance of precordial ST-segment depression in acute transmural inferior infarction: Coronary angiographic findings," Catheterization and cardiovascular diagnosis, vol. 9, no. 2, pp. 143-151, 1983.

[13]P. T. O'gara et al., "2013 ACCF/AHA guideline for the management of ST-elevation myocardial infarction: executive summary: a report of the American College of Cardiology Foundation/American Heart Association Task Force on Practice Guidelines," Journal of the American College of Cardiology, vol. 61, no. 4, pp. 485-510, 2013. 